\title{
Opposing Roles for Reactive Astrocytes following Traumatic Brain Injury
}

\author{
Melissa D. Laird John R. Vender Krishnan M. Dhandapani \\ Department of Neurosurgery, Medical College of Georgia, Augusta, Ga., USA
}

\section{Key Words}

Glia - Neurotrauma - Astrocyte - Gliosis - Neuroprotection • Inflammation - Brain edema $\cdot$ Controlled cortical impact, synaptic

\begin{abstract}
Traumatic brain injury (TBI) is a leading cause of death and disability in the United States. Current medical therapies exhibit limited efficacy in reducing neurological injury and the prognosis for patients remains poor. While most research is focused on the direct protection of neuronal cells, non-neuronal cells, such as astrocytes, may exert an active role in the pathogenesis of TBI. Astrocytes, the predominant cell type in the human brain, are traditionally associated with providing only structural support within the CNS. However, recent work suggests astrocytes may regulate brain homeostasis and limit brain injury. In contrast, reactive astrocytes may also contribute to increased neuroinflammation, the development of cerebral edema, and elevated intracranial pressure, suggesting possible roles in exacerbating secondary brain injury following neurotrauma. The multiple, opposing roles for astrocytes following neurotrauma may have important implications for the design of directed therapeutics to limit neurological injury. As such, a primary focus of this review is to summarize the emerging evidence suggesting reactive astrocytes influence the response of the brain to TBI.
\end{abstract}

Copyright $\odot 2008$ S. Karger AG, Basel
(C) 2008 S. Karger AG, Basel

$1424-862 X / 08 / 0163-0154 \$ 24.50 / 0$

Fax +4161306 1234 E-Mail karger@karger.ch www.karger.com
Accessible online at:

www.karger.com/nsg
Traumatic brain injury (TBI) is a leading cause of death and disability in the United States [1], placing a large economic burden on society ( USD $1.8 \mathrm{million} / \mathrm{pa}$ tient) due to a significant loss of productive years and the necessity for long term care. Although preventative measures (e.g. use of helmets, seat beats) have reduced the incidence of TBI, 1.5 million Americans suffer from a head injury annually and up to $2 \%$ of the population may live with neurological symptoms resulting from a brain trauma [2]. TBI, which affects twice as many patients as stroke injury, primarily results from motor vehicle accidents, falls, sports-related accidents, and military injuries. Despite exhaustive medical therapy, the prognosis for TBI patients remains poor, due in part to the development of cerebral edema, elevated intracranial pressure, neuronal and vascular injury, and long-term cognitive dysfunction. Thus, an improved mechanistic understanding of the pathogenesis of TBI is needed to develop more proactive strategies for intervention. The identification of novel neuroprotective compounds remains a primary interest; however, other cell types, such as astrocytes, may provide additional therapeutic targets to limit neurological injury. The idea that astrocytes actively contribute to the sequelae following a brain trauma is a relatively unexplored area of research; however, astrocytes may exhibit functions that appear diametrically opposed following neurotrauma. A primary focus of this review is to summarize the emerging evidence suggesting reactive astrocytes may exert both protective and detrimental roles following TBI.

Tel. +1 706721 8846, Fax +1 706721 7619, E-Mail kdhandapani@mcg.edu 


\section{Role of Astrocytes in Brain Physiology and Disease}

The Neurovascular Unit (NVU) is organized into discreet units comprised of neurons, astrocytes, and blood vessels. Astrocytes, the predominant cell type within the NVU, are ten-fold more prevalent in the human brain as compared to neurons [3]. A distinguishing feature of the adult human brain is the complexity and diversity of cortical astrocytes, which are nearly three times larger and contain tenfold more primary processes than rodent astrocytes [4]. Although beyond the scope of this review, the reader is directed toward an excellent, comprehensive discussion of the possible complex roles that astrocytes may serve in the human brain [4]. Although additional studies are required, these interesting findings indicate astrocytes may exert an important influence on human brain function. The dogmatic view of astrocytes as 'brain glue', providing structural scaffolding for surrounding neurons and blood vessels, was recently challenged by the notion that astrocytes may actively influence brain physiology [5]. Astrocytes are anatomically in juxtaposition to both neurons and blood vessels and contribute to the formation of the blood-brain barrier (BBB) [6-8], regulate cerebral blood flow in response to neuronal activity $[9$, $10]$, provide metabolic substrates for neurons [11, 12], and regulate oxidative balance in the brain [13]. Astrocytes constitutively express multiple ion transporters and neurotransmitter receptors, indicating an important role in the regulation of brain $\mathrm{pH}$ and neuronal excitability, and release soluble factors to promote neuronal signaling, survival and synaptic plasticity [14-18]. Furthermore, stimulation of astrocytic metabotropic glutamate receptors causes vasodilation whereas $\alpha_{1}$ - or $\beta$-adrenergic activation induces vasoconstriction, suggesting astrocytes can also mediate neuronal activity-dependent changes in blood flow [19]. Together, these findings support an active role for astrocytes in the regulation of brain physiology beyond structural support.

\section{Astrocytes: Friend or Foe following TBI?}

Although astrocytes clearly promote brain function in the uninjured brain, it remains unclear whether these beneficial roles are preserved, augmented, or lost by astrocytes after a head trauma. Following experimental TBI [20-22] or neurotrauma in humans [23], astrocytes undergo a phenotypic change deemed 'reactive astrocytosis', a process characterized by cellular hypertrophy and hyperplasia, cytoplasmic enlargement, elongated cytoplasmic processes, and increased expression of the glial-specific intermediate filament, glial fibrillary acidic protein (GFAP) $[24,25]$. S100 $\beta$, a marker of reactive astrocytosis, is elevated in the serum $[26,27]$ and CSF [28] of TBI patients and serum concentrations of GFAP correlate with clinical outcome following TBI [29]. Taken together, these data imply the magnitude of the astrocytic response may dictate the severity of brain injury in patients. While brain injury correlates with reactive astrocytosis, conflicting data also implicates astrocytes in brain protection/repair following TBI. The evidence documenting the diametrically opposing actions of astrocytes following injury is reviewed in the following sections.

\section{Protective Role of Reactive Astrocytes following TBI}

\section{Reactive Astrocytes Restrict Tissue Damage following TBI}

Delineating the precise contributions of reactive astrocytosis following brain trauma was previously hindered by the technical difficulties associated with studying the function of astrocytes in vivo. The generation of transgenic mice in which the herpes simplex virus thymidine kinase (HSV-TK) gene was specifically targeted to astrocytes using the glial fibrillary acidic protein (GFAP) promoter, provides a unique experimental model to study the reported conflicting effects of reactive astrocytes following TBI. As GFAP expression is dramatically upregulated following brain injury, subsequent ganciclovir administration (which is converted to a toxic compound by thymidine kinase) ablates reactive astrocytes without affecting nonreactive astrocytes that are spatially removed from the site of injury [30]. Elimination of reactive astrocytes reduced glial scar formation, exacerbated the magnitude and duration of inflammatory activation, and prolonged leukocyte infiltration, as compared to nontransgenic control mice, following forebrain stab injury or spinal cord injury [31, 32]. Conditional astrocyte ablation also exacerbated neural tissue damage and increased the inflammatory response following moderate TBI $[33,34]$. These data support the hypothesis that reactive astrocytes form a protective scar to contain the brain injury to a defined region, thereby sparing adjacent non-injured tissue from secondary injury [35]. Reactive astrocytes may also generate an adaptive inflammatory response to aid in the removal of damaged and dead tissue from the site of injury, creating an improved niche for a subsequent reparative response $[30,36,37]$. 
Reactive Astrocytes Repair the BBB following Injury

The immunologically privileged status of the brain is maintained by $\mathrm{BBB}$, which prevents the entry of large, blood-derived macromolecules. Brain injury increases the permeability of the $\mathrm{BBB}$, promoting vasogenic edema and elevated intracranial pressure. Ablation of reactive astrocytes reversed the endogenous ability of the BBB to repair, denuded astrocytic endfeet from blood vessels, and increased vasogenic edema following forebrain stab wound injury or spinal cord injury $[31,32]$. In an eloquent study, restoration of BBB integrity was induced by grafting astrocytes from nontransgenic mice into animals following removal of reactive astrocytes [31], demonstrating an important role for astrocytes in BBB repair following a brain injury. These findings are consistent with increased microvascular damage, disruption of the BBB, and an exaggerated inflammatory response following primary astrocyte loss in rodents [38-40].

\section{Reactive Astrocytes Allow Regenerative Process} following TBI

Cognitive dysfunction and long-term disability are a frequent result of diffuse axonal loss and neuronal damage. Reactive synaptogenesis, an endogenous repair mechanism, may provide limited neural regeneration following traumatic axonal injury [41, 42]. Thus, an improved understanding of this process may identify novel therapeutic targets to augment the reparative capacity of the brain. Prior to synaptic repair/regeneration, damaged extracellular matrix proteins must be degraded and cellular debris removed to establish a favorable environment for axonal regeneration. Reactive astrocytes release matrix metalloproteinases (MMP), a class of enzymes that exhibit diverse roles in the brain, including brain remodeling, synaptic function, degradation of the neurovascular matrix, BBB disruption, cerebral edema, and hemorrhagic transformation [43-52]. Of particular interest, MMP-3 modifies damaged extracellular matrix proteins and contributes to the clearance of necrotic debris, suggesting a possible reparative role. MMP-3 is expressed in reactive astrocytes in regions undergoing reactive synaptogenesis following TBI [53], aiding in the establishment of an environment that is conducive for neuritic outgrowth, synaptogenesis, and synapse maturation. In contrast, extended expression of MMP-3 may negatively affect brain recovery, demonstrating the importance of tight spatial and temporal regulation in mediating the biological actions of this enzyme [53]. Together, these data raise the possibility that astrocyte-derived MMP-3 may promote brain recovery and restoration of function- ally active synapses following brain injury, a finding which could be therapeutically exploited in the future.

Reactive astrocytes may establish an improved niche to permit neuronal reconnectivity and functional brain repair following TBI. Tissue culture studies also support a role for astrocyte-derived soluble factors, including cholesterol [54-56], tumor necrosis factor- $\alpha$ (TNF- $\alpha)$ [57, $58]$, thrombospondin [59], and TGF- $\beta[14,60]$ in directly promoting neuroplasticity and increased synaptic strength. Although significant work remains to delineate the precise functions of these factors following TBI, the temporal expression pattern may determine functional outcome. For example, TNF- $\alpha$ exacerbates neurovascular injury and BBB disruption following TBI [61]; however, continual exposure to glial-derived TNF- $\alpha$ preserved synaptic strength at excitatory synapses, in part, by modulating AMPA receptor trafficking $[57,58]$. Thus, TNF- $\alpha$ may exhibit a biphasic effect with the early expression of TNF- $\alpha$ promoting the degenerative process and the delayed expression contributing to synaptic repair. Similarly, TGF- $\beta$ is produced by reactive astrocytes $[62,63]$ and is increased in the CSF of TBI patients [64]. Although TGF- $\beta$ may enhance synaptogenesis [60], it also induces the expression of GFAP, laminin, and fibronectin, which limit axonal regeneration via the generation of the glial scar $[63,65,66]$. Delineating the precise role for each factor following TBI is technically challenging, but the advent of conditional and cell-type specific transgenic mice should provide new insights into the role(s) for these and other factors following brain injury. An improved understanding of the temporal expression and functional roles for each of these factors may result in the development of novel therapeutics, which exploit the beneficial aspects and minimize the detrimental effects of reactive astrocytes.

\section{Potential Damaging Roles for Astrocytes following TBI}

Nearly one-third of hospitalized TBI patients die from injuries that are secondary to the initial trauma, including increased neuroinflammation, disruption of the BBB, neuronal excitotoxicity, brain edema, and intracranial hypertension [67]. In addition to displaying protective and reparative functions, reactive astrocytes may also exert detrimental roles to exacerbate secondary brain injury. The following sections provide an overview of the evidence supporting a damaging role for reactive astrocytes following a head injury. 


\section{Glutamate Excitotoxicity}

Glutamate excitotoxicity is an important cause of neuronal damage following head injury $[68,69]$. Concentrations of glutamate within the brain and CSF correlate with the severity of injury following TBI [70-74], supporting a possible benefit of limiting glutamatergic signaling. Consistent with this assertion, administration of antagonists to the NMDA receptor (a glutamate receptor subtype) reduced brain injury in animal models of TBI $[31,75,76]$. Unfortunately, clinical trials with NMDA receptor antagonists were associated with intolerable side effects, poor drug efficacy, limited therapeutic windows, and interference with normal synaptic transmission. Thus, targeting the NMDA receptor likely represents a suboptimal therapeutic target, demonstrating the need to identify novel strategies to limit excitotoxicity [77-80]. The astrocytic glutamate transporters, GLT-1 and GLAST, regulate extracellular glutamate and limit neuronal excitotoxicity by clearing excess glutamate [81-85]. However, both GLT-1 and GLAST are downregulated following TBI in rodents [86] and humans [87], suggesting dysfunctional regulation of astrocytic glutamate transporters may exacerbate neuronal excitotoxicity following head trauma. It is therefore tempting to speculate that modulation of glial glutamate transporters may represent a novel approach to limit secondary excitotoxicity after head injury. Together, these findings imply that preservation of astrocytic function and viability may reduce secondary neuronal injury following TBI, at least in part, by maintaining glutamate homeostasis.

\section{Inflammation}

The activation of the complex inflammatory cascade is an important, yet incompletely understood, component of the brain response to an injury. Although it remains controversial whether inflammation is beneficial or detrimental following TBI $[88,89]$, the acute release of pro-inflammatory cytokines clearly influences multiple cell types in the CNS. This section provides a brief overview of several pro-inflammatory mediators which localize in reactive astrocytes and which may influence outcome following TBI. For more comprehensive coverage of inflammation and head injury, the reader is directed toward several excellent reviews [88, 89].

Tumor necrosis factor- $\alpha$ (TNF- $\alpha$ ) is a $17-\mathrm{kDa}$ peptide that activates TNF receptors (TNFR) on glia and neurons $[90,91]$. TNF- $\alpha$ is elevated in the CSF of neurotrauma patients within the first $24 \mathrm{~h}$ of injury [28] and the acute release of TNF- $\alpha$ from neurons and/or glia is a primary mediator of inflammatory activation and gliosis follow- ing experimental TBI [92-101]. Mice deficient in TNF- $\alpha$ exhibit improved motor performance, enhanced spatial memory acquisition, and decreased brain injury following TBI, suggesting a possible detrimental role for TNF- $\alpha$ following head trauma $[61,93]$; however, another report suggested these mice recovered motor function more slowly than wild-type controls following TBI [102]. Additionally, exogenous TNF- $\alpha$ induced resistance to acidosis and calcium ionophore toxicity in astrocytes [103], indicating a protective function following brain injury $[104,105]$. Consistent with a possible beneficial role for endogenous TNF- $\alpha$, TNFR-deficient mice exhibited an exacerbation of lesion volume and BBB disruption following experimental TBI [106]. These effects were associated with the delayed activation of the NFKB transcription factor and reduced expression of the antioxidant enzyme, manganese superoxide dismutase (MnSOD), following injury in TNFR-deficient mice [106]. These results suggest endogenous TNF- $\alpha$ may upregulate antioxidant pathways to preserve tissue function. Although the mechanisms underlying these differential effects remain unknown, the divergent effects of TNF- $\alpha$ likely represent a balance between opposing signaling pathways to regulate survival and death $[96,107,108]$. Along these lines, TNF- $\alpha$ induces an acute inflammatory response via activation of $\mathrm{NF \kappa B}$ and AP-1 transcription factors [109-111]; however rapid, transient activation of the JNK signaling pathway, which enhances AP-1 and NFKB-mediated transcription, induces survival signaling whereas prolonged activation is associated with proapoptotic signaling $[108,112,113]$. Consequently, an improved understanding of the temporal pattern of TNFR activation may provide important new insights into the dual role of TNF- $\alpha$.

Fas (CD95) is a transmembrane glycoprotein within the TNF- $\alpha$ receptor superfamily that binds Fas ligand (FasL) to regulate microglial apoptosis and pro-inflammatory activation in astrocytes [114]. Fas, which is implicated in excitotoxic neuronal cell death in vivo [115], is acutely increased following experimental TBI and remains elevated for more than three days following injury $[116,117]$. Fas inhibition attenuates cellular damage following TBI, stroke, and spinal cord injury [61, 118-121], suggesting a detrimental role following brain injury. In contrast, Fas may also promote regeneration within the nervous system [122], including neuritic outgrowth and branching $[123,124]$, functional recovery following sciatic nerve and spinal cord injury $[119,124]$, and protection against neurodegeneration in experimental models of Parkinson's disease [125]. 
Arachidonic acid, which promotes glial swelling and brain edema (see next section for discussion) [126], is converted to prostaglandins by cyclo-oxygenase (COX) enzymes [127-129]. The inducible COX isoform, COX-2, is expressed in both neurons and glia following experimental TBI [130]. COX-2-dependent prostaglandin formation is implicated in brain injury following TBI, including increased white matter injury, vasoconstriction, BBB disruption, brain edema, elevated intracranial pressure, and cognitive and motor dysfunction [129-133]. In support of a damaging role for COX-2, nimesulide, a potent non-steroidal anti-inflammatory drug (NSAID), reversed TBI-induced motor and cognitive dysfunction in rats $[133,134]$. In contrast, the FDA-approved COX-2 inhibitor, celecoxib, worsened motor performance following TBI [135] and rofecoxib failed to limit brain injury [132]. Thus, despite a large body of evidence suggesting an injurious role for COX-2, the ability of COX-2 inhibitors to limit neurological injury following TBI remains controversial. Coupled with an increased risk of vascular dysfunction associated with current COX-2 inhibitors, these data do not support therapeutic targeting of COX-2 to improve outcome following brain injury.

IL-1 $\beta$ is rapidly induced following a brain injury and induces the reactive astrocytotic phenotype $[136,137]$. Elevated concentrations of IL- $1 \beta$ in the CSF of neurotrauma patients are associated with an unfavorable clinical outcome $[28,138,139]$ and IL-1 $\beta$ gene and protein expression directly correlate with injury severity following experimental TBI in rodents [140]. IL-1 $\beta$ is induced in both neurons and glial cells and the administration of neutralizing antibodies against IL-1 $\beta$ attenuated hippocampal neurotoxicity following TBI, suggesting an important role for IL-1 $\beta$ in neuronal injury following brain trauma [125]. In further support of an injurious role, IL$1 \beta$ increases the production of other pro-inflammatory mediators, including COX-2, prostaglandins, nitric oxide, matrix metalloproteinases, TNF- $\alpha$ and may regulate further production of IL-1 $\beta$, providing a positive feedback loop of inflammatory activation [141-143]. In contrast, IL-1 $\beta$ may also exhibit protective and/or regenerative effects in the brain by increasing the expression of trophic factors, including fibroblast growth factor [144], transforming growth factor- $\beta 1$ [145], ciliary neurotrophic factor [146], nerve growth factor [147], and insulin-like growth factor [148]. As with other astrocyte-derived factors, these data support a dual role for IL- $1 \beta$ following brain injury and emphasize the likely importance of spatial and temporal regulation in mediating biological activity.

\section{Brain Edema}

Brain edema, defined as the abnormal accumulation of fluid within the brain parenchyma, is a serious neurological complication that contributes to elevated intracranial pressure, brain herniation, and a poor prognosis following head trauma [149-152]. Clinically, the degree of swelling on the first computed tomography (CT) scan directly correlates with patient outcome, demonstrating the need to reduce acute brain edema following head injury [153]. The mechanisms underlying the development of brain edema following TBI remain poorly defined; however, both vasogenic and cellular edema may contribute to brain swelling [154]. Vasogenic edema, which originates when fluid from blood vessels enters the brain secondary to traumatic opening of the $\mathrm{BBB}$, was long believed to be the primary form of fluid accumulation [155-157]. In contrast, recent studies suggest cellular edema, which is caused by fluid accumulation within cells following an injury, may be more prevalent following TBI $[158,159]$. Disruption of ionic homeostasis following brain injury is a primary cause of cellular edema by increasing sodium entry into the brain, causing tissue swelling [160-162]. Astrocytic swelling, an important component of cellular edema [163], occurs within the first hours following cortical contusion in humans [164] and is associated with the accumulation of extracellular potassium ions and a reduction in extracellular sodium, calcium, and chloride ions $[165,166]$. Astrocytic swelling also inhibits glutamate uptake while inducing the release of excitatory amino acids (e.g. glutamate), contributing to the activation of ligand-gated ion channels and ionic movement against the electrochemical gradient [167]. Although significant work remains, the therapeutic targeting of $\mathrm{Na}^{+} / \mathrm{H}^{+}$transporters, $\mathrm{Na}^{+} / \mathrm{Ca}^{2+}$ exchangers, or $\mathrm{Na}^{+} /$ $\mathrm{K}^{+} / 2 \mathrm{Cl}^{-}$cotransporters may promote a mechanism to restore ionic homeostasis. This possibility is supported by the ability of fluorenyl drugs to alleviate astrocytic swelling and cellular edema following brain injury $[168,169]$.

Aquaporins, a family of water transporters consisting of 11 members, provide another possible therapeutic target to limit brain water accumulation following head injury. Aquaporin-4 (AQP4), which is expressed primarily in the perivascular endfeet of astrocytes [170], mediates fast water transport in cultured astrocytes [171], suggesting a possible role in the rapid formation of edema following brain injury. While an understanding of the relationship between AQP4 and brain edema remains incomplete [172], AQP4 appears to increase cellular edema, yet aids in the resolution of vasogenic edema [173]. In support of a role for AQP4 in water retention, transgenic mice that 
are deficient in AQP4 exhibited improved survival, decreased brain edema, and a reduction in the swelling of pericapillary astrocytic foot processes following ischemic stroke or acute water intoxication model of brain edema [174-177]. With respect to TBI, AQP4 is elevated within or around the injury site and was associated with increased brain edema and disruption of the BBB $[135,178$ 180], supporting a role for AQP4 in the development of brain edema following TBI. It is also interesting that genetic deletion of AQP4 also attenuated scar formation, an effect which may be attributed to the role of AQP4 in astrocyte migration to the injury site. Although still poorly understood, AQP4 may affect astrocytic morphology during migration and glial scar formation by facilitating water movement $[181,182]$. Together, these studies suggest AQP4 may exert diverse roles on astrocytic function following brain injury, implicating AQP4 as a future therapeutic target following brain injury.

\section{Wound Healing}

The pioneering work of Ramon y Cajal nearly one century ago remarked that injured axons within the CNS were unable to regenerate following a brain injury. Although protective functions for the glial scar are proposed (see above sections) reactive astrocytes also may limit functional recovery following brain trauma. Within the first days following brain injury, reactive astrocytes restrict tissue injury by migrating from the uninjured tissue to the area of injury. Subsequently, reactive astrocytes express the structural filament proteins, GFAP and vimentin, and interdigitate their processes to create dense plexus - a process called anisomorphic gliosis [183-185]. The newly formed glial scar, which consists of deposited extracellular matrix molecules, likely restricts neural repair and axonal regeneration following TBI [183, 186]. This notion is supported by the observation that axonal regeneration is increased in transgenic mice lacking the genes for GFAP or vimentin, which are preferentially expressed by reactive astrocytes [187]. Chemical removal of glial cells from the medial forebrain bundle following transection of the nigrostriatal tract also resulted in the dramatic and rapid growth of new axons through the gli- al-free zone [188]. However, astrocytes reappeared within one week and formed an anisomorphic glial scar, which correlated with the absence of new regenerating fibers. Similarly, genetic ablation of reactive astrocytes increased axonal growth following a stab wound injury through the cortex and hippocampus [31]; further indicating the glial scar may limit axonal regeneration following a brain injury. Although these data suggest that removal of reactive astrocytes may be a beneficial therapeutic strategy to promote brain repair, astrocytic ablation was also associated with a failure of the BBB to reseal following injury [31]. These interesting data suggest astrocytes contribute to multiple processes and emphasize the importance of understanding the temporal regulation of reactive astrocytic factors in the pathogenesis of TBI.

\section{Future Roles for Astrocytes as Therapeutic Targets following TBI}

TBI remains a major health issue, debilitating or killing a large number of young adults. Unfortunately, most clinical trials have proven unsuccessful and the current treatment strategies remain limited. Although the precise contributions of reactive astrocytes to the pathogenesis of TBI remain controversial and largely unexplored, recent data suggest the possibility of targeting astrocytes to limit neurovascular injury and promote functional brain repair. For example, an improved understanding of the temporal and spatial regulation of inflammatory mediators may improve the therapeutic targeting of these pathways to exploit the beneficial aspects (e.g. clearance of tissue debris, improved niche for neural repair) and minimize the associated pathology associated with inflammation (edema, neuronal damage). The advent of cell-specific, single gene knockout mice may clarify the opposing functions currently associated with reactive astrocytes following TBI. These exciting possibilities should provide a fruitful area of future research to further elucidate the mechanisms underlying the brain response to head trauma and could yield novel treatment strategies, which potentiate the protective aspects of reactive astrocytes while minimizing the deleterious effects.

\section{References}

1 Nortje J, Menon DK: Traumatic brain injury: physiology, mechanisms, and outcome. Curr Opin Neurol 2004;17:711-718.

2 Bramlett HM, Dietrich WD: Pathophysiology of cerebral ischemia and brain trauma: similarities and differences. J Cereb Blood Flow Metab 2004;24:133-150.
3 Bignami A: Glial cells in the central nervous system; in Magistretti PJ (ed): Discussions in Neuroscience. Amsterdam, Elsevier, 1991, vol VIII, pp 1-45.

-4 Oberheim NA, Wang X, Goldman S, Nedergaard M: Astrocytic complexity distinguishes the human brain. Trends Neurosci 2006; 29:547-553. 
$>5$ Volterra A, Meldolesi J: Astrocytes, from brain glue to communication elements: the revolution continues. Nat Rev Neurosci 2005;6:626-640.

6 Abbott NJ, Revest PA, Romero IA: Astrocyte-endothelial interaction: physiology and pathology. Neuropathol Appl Neurobiol 1992;18:424-433.

7 Hayashi Y, Nomura M, Yamagishi S, Harada $\mathrm{S}$, Yamashita J, Yamamoto H: Induction of various blood-brain barrier properties in non-neural endothelial cells by close apposition to co-cultured astrocytes. Glia 1997;19: 13-26.

$\checkmark 8$ Janzer RC, Raff MC: Astrocytes induce blood-brain barrier properties in endothelial cells. Nature 1987;325:253-257.

-9 Iadecola C: Neurovascular regulation in the normal brain and in Alzheimer's disease. Nat Rev Neurosci 2004;5:347-360.

-10 Takano T, Tian GF, Peng W, Lou N, Libionka W, Han X, Nedergaard M: Astrocyte-mediated control of cerebral blood flow. Nat Neurosci 2006;9:260-267.

-11 Bouzier-Sore AK, Merle M, Magistretti PJ, Pellerin L: Feeding active neurons: (re)emergence of a nursing role for astrocytes. J Physiol (Paris) 2002;96:273-282.

$\checkmark 12$ Pellerin L, Magistretti PJ: Neuroenergetics: calling upon astrocytes to satisfy hungry neurons. Neuroscientist 2004;10:53-62.

$\checkmark 13$ Wilson JX: Antioxidant defense of the brain: a role for astrocytes. Can J Physiol Pharmacol 1997;75:1149-1163.

-14 Dhandapani KM, Hadman M, De Sevilla L, Wade MF, Mahesh VB, Brann DW: Astrocyte protection of neurons: role of transforming growth factor-beta signaling via a c-Jun-AP-1 protective pathway. J Biol Chem 2003;278:43329-43339.

-15 Dhandapani KM, Wade FM, Mahesh VB, Brann DW: Astrocyte-derived transforming growth factor-\{beta\} mediates the neuroprotective effects of 17 \{beta\}-estradiol: involvement of nonclassical genomic signaling pathways. Endocrinology 2005; 146:2749-2759.

-16 Pfrieger FW, Barres BA: Synaptic efficacy enhanced by glial cells in vitro. Science 1997; 277:1684-1687.

17 Ullian EM, Christopherson KS, Barres BA: Role for glia in synaptogenesis. Glia 2004;47: 209-216.

18 Ullian EM, Sapperstein SK, Christopherson KS, Barres BA: Control of synapse number by glia. Science 2001;291:657-661.

$\checkmark 19$ Jakovcevic D, Harder DR: Role of astrocytes in matching blood flow to neuronal activity. Curr Top Dev Biol 2007;79:75-97.

-20 Cortez SC, McIntosh TK, Noble LJ: Experimental fluid percussion brain injury: vascular disruption and neuronal and glial alterations. Brain Res 1989;482:271-282.

-21 Hill SJ, Barbarese E, McIntosh TK: Regional heterogeneity in the response of astrocytes following traumatic brain injury in the adult rat. J Neuropathol Exp Neurol 1996;55:12211229.
22 Dietrich WD, Truettner J, Zhao W, Alonso OF, Busto R, Ginsberg MD: Sequential changes in glial fibrillary acidic protein and gene expression following parasagittal fluidpercussion brain injury in rats. J Neurotrauma 1999;16:567-581.

23 Castejon OJ: Morphological astrocytic changes in complicated human brain trauma: a light and electron microscopic study. Brain Inj 1998;12:409-427; discussion 407.

24 Baldwin SA, Scheff SW: Intermediate filament change in astrocytes following mild cortical contusion. Glia 1996;16:266-275.

25 Amaducci L, Forno KI, Eng LF: Glial fibrillary acidic protein in cryogenic lesions of the rat brain. Neurosci Lett 1981;21:27-32

26 Pelinka LE, Toegel E, Mauritz W, Redl H: Serum S 100 B: a marker of brain damage in traumatic brain injury with and without multiple trauma. Shock 2003;19:195-200.

27 Pelinka LE, Kroepfl A, Leixnering M, Buchinger W, Raabe A, Redl H: GFAP versus S100B in serum after traumatic brain injury: relationship to brain damage and outcome. J Neurotrauma 2004;21:1553-1561.

28 Hayakata T, Shiozaki T, Tasaki O, Ikegawa $\mathrm{H}$, Inoue Y, Toshiyuki F, Hosotubo H, Kieko F, Yamashita T, Tanaka H, Shimazu T, Sugimoto H: Changes in CSF S100B and cytokine concentrations in early-phase severe traumatic brain injury. Shock 2004;22:102-107.

29 Pelinka LE, Kroepfl A, Schmidhammer R, Krenn M, Buchinger W, Redl H, Raabe A: Glial fibrillary acidic protein in serum after traumatic brain injury and multiple trauma. J Trauma 2004;57:1006-1012.

30 Sofroniew MV: Reactive astrocytes in neural repair and protection. Neuroscientist 2005; 11:400-407.

-31 Bush TG, Puvanachandra N, Horner CH, Polito A, Ostenfeld T, Svendsen CN, Mucke L, Johnson MH, Sofroniew MV: Leukocyte infiltration, neuronal degeneration, and neurite outgrowth after ablation of scarforming, reactive astrocytes in adult transgenic mice. Neuron 1999;23:297-308.

32 Faulkner JR, Herrmann JE, Woo MJ, Tansey KE, Doan NB, Sofroniew MV: Reactive astrocytes protect tissue and preserve function after spinal cord injury. J Neurosci 2004;24: 2143-2155.

>33 Cui W, Allen ND, Skynner M, Gusterson B, Clark AJ: Inducible ablation of astrocytes shows that these cells are required for neuronal survival in the adult brain. Glia 2001;34: 272-282.

34 Myer DJ, Gurkoff GG, Lee SM, Hovda DA, Sofroniew MV: Essential protective roles of reactive astrocytes in traumatic brain injury. Brain 2006;129:2761-2772.

35 Fitch MT, Silver J: Glial cell extracellular matrix: boundaries for axon growth in development and regeneration. Cell Tissue Res 1997; 290:379-384.
36 Kawaja MD, Gage FH: Reactive astrocytes are substrates for the growth of adult CNS axons in the presence of elevated levels of nerve growth factor. Neuron 1991;7:10191030

\37 Hamill CE, Goldshmidt A, Nicole O, McKeon RJ, Brat DJ, Traynelis SF: Special lecture: glial reactivity after damage: implications for scar formation and neuronal recovery. Clin Neurosurg 2005;52:29-44

38 Willis CL, Nolan CC, Reith SN, Lister T, Prior MJ, Guerin CJ, Mavroudis G, Ray DE: Focal astrocyte loss is followed by microvascular damage, with subsequent repair of the blood-brain barrier in the apparent absence of direct astrocytic contact. Glia 2004;45: 325-337.

39 Prior MJ, Brown AM, Mavroudis G, Lister T, Ray DE: MRI characterisation of a novel rat model of focal astrocyte loss. Magma 2004; 17:125-132.

40 Willis CL, Leach L, Clarke GJ, Nolan CC, Ray DE: Reversible disruption of tight junction complexes in the rat blood-brain barrier, following transitory focal astrocyte loss. Glia 2004;48:1-13.

41 Povlishock JT, Christman CW: The pathobiology of traumatically induced axonal injury in animals and humans: a review of current thoughts. J Neurotrauma 1995;12:555-564.

42 Steward O: Reorganization of neuronal connections following CNS trauma: principles and experimental paradigms. J Neurotrauma 1989;6:99-152.

$\checkmark 43$ Reeves TM, Prins ML, Zhu J, Povlishock JT, Phillips LL: Matrix metalloproteinase inhibition alters functional and structural correlates of deafferentiation-induced sprouting in the dentate gyrus. J Neurosci 2003;23: 10182-10189.

44 Szklarczyk A, Lapinska J, Rylski M, McKay RD, Kaczmarek L: Matrix metalloproteinase-9 undergoes expression and activation during dendritic remodeling in adult hippocampus. J Neurosci 2002;22:920-930.

45 Ethell IM, Ethell DW: Matrix metalloproteinases in brain development and remodeling: Synaptic functions and targets. J Neurosci Res 2007;85:2813-2823.

46 Bozdagi O, Nagy V, Kwei KT, Huntley GW: In vivo roles for matrix metalloproteinase-9 in mature hippocampal synaptic physiology and plasticity. J Neurophysiol 2007;98:334344.

-47 Muir EM, Adcock KH, Morgenstern DA, Clayton R, von Stillfried N, Rhodes K, Ellis C, Fawcett JW, Rogers JH: Matrix metalloproteases and their inhibitors are produced by overlapping populations of activated astrocytes. Brain Res Mol Brain Res 2002;100: 103-117.

48 Asahi M, Wang X, Mori T, Sumii T, Jung JC, Moskowitz MA, Fini ME, Lo EH: Effects of matrix metalloproteinase-9 gene knock-out on the proteolysis of blood-brain barrier and white matter components after cerebral ischemia. J Neurosci 2001;21:7724-7732. 
-49 Mori T, Wang X, Aoki T, Lo EH: Downregulation of matrix metalloproteinase- 9 and attenuation of edema via inhibition of ERK mitogen activated protein kinase in traumatic brain injury. J Neurotrauma 2002;19:14111419.

-50 Rosenberg GA: Matrix metalloproteinases in brain injury. J Neurotrauma 1995;12:833842 .

-51 Wang X, Jung J, Asahi M, Chwang W, Russo L, Moskowitz MA, Dixon CE, Fini ME, Lo $\mathrm{EH}$ : Effects of matrix metalloproteinase-9 gene knock-out on morphological and motor outcomes after traumatic brain injury. J Neurosci 2000;20:7037-7042.

-52 Sifringer M, Stefovska V, Zentner I, Hansen B, Stepulak A, Knaute C, Marzahn J, Ikonomidou C: The role of matrix metalloproteinases in infant traumatic brain injury. Neurobiol Dis 2007;25:526-535.

-53 Falo MC, Fillmore HL, Reeves TM, Phillips LL: Matrix metalloproteinase-3 expression profile differentiates adaptive and maladaptive synaptic plasticity induced by traumatic brain injury. J Neurosci Res 2006;84:768781.

54 Goritz C, Mauch DH, Nagler K, Pfrieger FW: Role of glia-derived cholesterol in synaptogenesis: new revelations in the synapse-glia affair. J Physiol (Paris) 2002;96:257-263.

55 Goritz C, Mauch DH, Pfrieger FW: Multiple mechanisms mediate cholesterol-induced synaptogenesis in a CNS neuron. Mol Cell Neurosci 2005;29:190-201.

-56 Mauch DH, Nagler K, Schumacher S, Goritz C, Muller EC, Otto A, Pfrieger FW: CNS synaptogenesis promoted by glia-derived cholesterol. Science 2001;294:1354-1357.

57 Beattie EC, Stellwagen D, Morishita W, Bresnahan JC, Ha BK, Von Zastrow M, Beattie MS, Malenka RC: Control of synaptic strength by glial TNF-alpha. Science 2002; 295:2282-2285

58 Stellwagen D, Malenka RC: Synaptic scaling mediated by glial TNF-alpha. Nature 2006; 440:1054-1059.

-59 Christopherson KS, Ullian EM, Stokes CC, Mullowney CE, Hell JW, Agah A, Lawler J, Mosher DF, Bornstein P, Barres BA: Thrombospondins are astrocyte-secreted proteins that promote CNS synaptogenesis. Cell 2005; 120:421-433.

60 Packard M, Mathew D, Budnik V: Wnts and TGF beta in synaptogenesis: old friends signalling at new places. Nat Rev Neurosci 2003;4:113-120.

-61 BermpohlD, YouZ, Lo EH, Kim HH, Whalen MJ: TNF alpha and Fas mediate tissue damage and functional outcome after traumatic brain injury in mice. J Cereb Blood Flow Metab 2007;27:1806-1818.

-62 da Cunha A, Jefferson JJ, Tyor WR, Glass JD, Jannotta FS, Vitkovic L: Control of astrocytosis by interleukin-1 and transforming growth factor-beta 1 in human brain. Brain Res 1993;631:39-45.
63 Logan A, Frautschy SA, Gonzalez AM, Sporn $\mathrm{MB}$, Baird A: Enhanced expression of transforming growth factor beta 1 in the rat brain after a localized cerebral injury. Brain Res 1992;587:216-225.

64 Morganti-Kossmann MC, Hans VH, Lenzlinger PM, Dubs R, Ludwig E, Trentz O, Kossmann T: TGF-beta is elevated in the CSF of patients with severe traumatic brain injuries and parallels blood-brain barrier function. J Neurotrauma 1999;16:617-628.

65 Logan A, Berry M, Gonzalez AM, Frautschy SA, Sporn MB, Baird A: Effects of transforming growth factor beta 1 on scar production in the injured central nervous system of the rat. Eur J Neurosci 1994;6:355-363.

66 Logan A, Green J, Hunter A, Jackson R, Berry $M$ : Inhibition of glial scarring in the injured rat brain by a recombinant human monoclonal antibody to transforming growth factor-beta2. Eur J Neurosci 1999;11: 2367-2374.

67 Miller JD, Jones PA, Dearden NM, Tocher JL: Progress in the management of head injury. Br J Surg 1992;79:60-64.

68 Palmer AM, Marion DW, Botscheller ML, Swedlow PE, Styren SD, DeKosky ST: Traumatic brain injury-induced excitotoxicity assessed in a controlled cortical impact model. J Neurochem 1993;61:2015-2024.

69 Obrenovitch TP, Urenjak J: Is high extracellular glutamate the key to excitotoxicity in traumatic brain injury? J Neurotrauma 1997; 14:677-698.

70 Yamamoto T, Rossi S, Stiefel M, Doppenberg E, Zauner A, Bullock R, Marmarou A: CSF and ECF glutamate concentrations in head injured patients. Acta Neurochir 1999;75 (suppl):17-19.

71 Bullock R, Zauner A, Woodward JJ, Myseros J, Choi SC, Ward JD, Marmarou A, Young HF: Factors affecting excitatory amino acid release following severe human head injury. J Neurosurg 1998;89:507-518.

72 Bullock R, Zauner A, Myseros JS, Marmarou A, Woodward JJ, Young HF: Evidence for prolonged release of excitatory amino acids in severe human head trauma. Relationship to clinical events. Ann NY Acad Sci 1995; 765:290-297; discussion 298.

73 Zhang X, Qiu M, Zhang X, Zhang J, Zhang $\mathrm{H}$, Kang D: Excitatory amino acids in cerebrospinal fluid and their relations with clinical features and outcomes in acute head injury. Chin Med J (Engl) 1998;111:978-981.

74 Zhang H, Zhang X, Zhang T, Chen L: Excitatory amino acids in cerebrospinal fluid of patients with acute head injuries. Clin Chem 2001;47:1458-1462.

75 Phillips LL, Lyeth BG, Hamm RJ, Reeves TM, Povlishock JT: Glutamate antagonism during secondary deafferentation enhances cognition and axo-dendritic integrity after traumatic brain injury. Hippocampus 1998; 8:390-401.
76 Faden AI, O’Leary DM, Fan L, Bao W, Mullins PG, Movsesyan VA: Selective blockade of the mGluR1 receptor reduces traumatic neuronal injury in vitro and improves outcome after brain trauma. Exp Neurol 2001; 167:435-444

77 Muir KW: Glutamate-based therapeutic approaches: clinical trials with NMDA antagonists. Curr Opin Pharmacol 2006;6:53-60.

78 Roesler R, Quevedo J, Schroder N: Is it time to conclude that NMDA antagonists have failed? Lancet Neurol 2003;2:13; discussion 13.

79 Ikonomidou C, Turski L: Why did NMDA receptor antagonists fail clinical trials for stroke and traumatic brain injury? Lancet Neurol 2002;1:383-386.

80 Hoyte L, Barber PA, Buchan AM, Hill MD: The rise and fall of NMDA antagonists for ischemic stroke. Curr Mol Med 2004;4:131136 .

81 Lehre KP, Levy LM, Ottersen OP, StormMathisen J, Danbolt NC: Differential expression of two glial glutamate transporters in the rat brain: quantitative and immunocytochemical observations. J Neurosci 1995;15: 1835-1853.

82 Ullensvang K, Lehre KP, Storm-Mathisen J, Danbolt NC: Differential developmental expression of the two rat brain glutamate transporter proteins GLAST and GLT. Eur J Neurosci 1997;9:1646-1655.

83 Rothstein JD, Dykes-Hoberg M, Pardo CA, Bristol LA, Jin L, Kuncl RW, Kanai Y, Hediger MA, Wang Y, Schielke JP, Welty DF: Knockout of glutamate transporters reveals a major role for astroglial transport in excitotoxicity and clearance of glutamate. Neuron 1996;16:675-686.

84 Pawlak J, Brito V, Kuppers E, Beyer C: Regulation of glutamate transporter GLAST and GLT-1 expression in astrocytes by estrogen. Brain Res Mol Brain Res 2005;138:1-7.

85 Rao VL, Dogan A, Todd KG, Bowen KK, Kim BT, Rothstein JD, Dempsey RJ: Antisense knockdown of the glial glutamate transporter GLT-1, but not the neuronal glutamate transporter EAAC1, exacerbates transient focal cerebral ischemia-induced neuronal damage in rat brain. J Neurosci 2001;21: 1876-1883

86 Rao VL, Baskaya MK, Dogan A, Rothstein JD, Dempsey RJ: Traumatic brain injury down-regulates glial glutamate transporter (GLT-1 and GLAST) proteins in rat brain. J Neurochem 1998;70:2020-2027.

-87 Beschorner R, Dietz K, Schauer N, Mittelbronn M, Schluesener HJ, Trautmann K, Meyermann R, Simon P: Expression of EAAT1 reflects a possible neuroprotective function of reactive astrocytes and activated microglia following human traumatic brain injury. Histol Histopathol 2007;22:515-526.

88 Morganti-Kossmann MC, Rancan M, Stahel PF, Kossmann T: Inflammatory response in acute traumatic brain injury: a double-edged sword. Curr Opin Crit Care 2002;8:101-105. 
89 Morganti-Kossmann MC, Rancan M, Otto VI, Stahel PF, Kossmann T: Role of cerebral inflammation after traumatic brain injury: a revisited concept. Shock 2001;16:165177.

$\$ 90$ Merrill JE: Effects of interleukin-1 and tumor necrosis factor-alpha on astrocytes, microglia, oligodendrocytes, and glial precursors in vitro. Dev Neurosci 1991;13:130137.

-91 Wolvers DA, Marquette C, Berkenbosch F, Haour F: Tumor necrosis factor-alpha: specific binding sites in rodent brain and pituitary gland. Eur Cytokine Netw 1993;4: 377-381.

92 Knoblach SM, Fan L, Faden AI: Early neuronal expression of tumor necrosis factoralpha after experimental brain injury contributes to neurological impairment. J Neuroimmunol 1999;95:115-125.

93 Shohami E, Ginis I, Hallenbeck JM: Dual role of tumor necrosis factor alpha in brain injury. Cytokine Growth Factor Rev 1999; 10:119-130.

-94 Taupin V, Toulmond S, Serrano A, Benavides J, Zavala F: Increase in IL-6, IL-1 and TNF levels in rat brain following traumatic lesion. Influence of pre- and post-traumatic treatment with Ro5 4864, a peripheraltype ( $\mathrm{p}$ site) benzodiazepine ligand. J Neuroimmunol 1993;42:177-185.

$\$ 95$ Vitarbo EA, Chatzipanteli K, Kinoshita K, Truettner JS, Alonso OF, Dietrich WD: Tumor necrosis factor alpha expression and protein levels after fluid percussion injury in rats: the effect of injury severity and brain temperature. Neurosurgery 2004;55: 416-424; discussion 424-415.

-96 Lotocki G, Alonso OF, Dietrich WD, Keane RW: Tumor necrosis factor receptor 1 and its signaling intermediates are recruited to lipid rafts in the traumatized brain. J Neurosci 2004;24:11010-11016.

-97 Shohami E, Bass R, Wallach D, Yamin A, Gallily R: Inhibition of tumor necrosis factor alpha (TNFalpha) activity in rat brain is associated with cerebroprotection after closed head injury. J Cereb Blood Flow Metab 1996;16:378-384.

-98 Shohami E, Gallily R, Mechoulam R, Bass $\mathrm{R}$, Ben-Hur T: Cytokine production in the brain following closed head injury: dexanabinol (HU-211) is a novel TNF-alpha inhibitor and an effective neuroprotectant. J Neuroimmunol 1997;72:169-177.

-99 Fan L, Young PR, Barone FC, Feuerstein GZ, Smith DH, McIntosh TK: Experimental brain injury induces differential expression of tumor necrosis factor-alpha mRNA in the CNS. Brain Res Mol Brain Res 1996; 36:287-291.

100 Feuerstein GZ, Liu T, Barone FC: Cytokines, inflammation, and brain injury: role of tumor necrosis factor-alpha. Cerebrovasc Brain Metab Rev 1994;6:341-360.
101 Rostworowski M, Balasingam V, Chabot S, Owens T, Yong VW: Astrogliosis in the neonatal and adult murine brain post-trauma: elevation of inflammatory cytokines and the lack of requirement for endogenous interferon-gamma. J Neurosci 1997;17: 3664-3674.

102 Scherbel U, Raghupathi R, Nakamura M, Saatman KE, Trojanowski JQ, Neugebauer E, Marino MW, McIntosh TK: Differential acute and chronic responses of tumor necrosis factor-deficient mice to experimental brain injury. Proc Natl Acad Sci USA 1999;96:8721-8726.

103 Mattson MP, Cheng B, Baldwin SA, SmithSwintosky VL, Keller J, Geddes JW, Scheff SW, Christakos S: Brain injury and tumor necrosis factors induce calbindin D-28k in astrocytes: evidence for a cytoprotective response. J Neurosci Res 1995;42:357-370.

104 Cheng B, Christakos S, Mattson MP: Tumor necrosis factors protect neurons against metabolic-excitotoxic insults and promote maintenance of calcium homeostasis. Neuron 1994;12:139-153.

105 Bruce AJ, Boling W, Kindy MS, Peschon J, Kraemer PJ, Carpenter MK, Holtsberg FW, Mattson MP: Altered neuronal and microglial responses to excitotoxic and ischemic brain injury in mice lacking TNF receptors. Nat Med 1996;2:788-794

106 Sullivan PG, Bruce-Keller AJ, Rabchevsky AG, Christakos S, Clair DK, Mattson MP, Scheff SW: Exacerbation of damage and altered NF-kappaB activation in mice lacking tumor necrosis factor receptors after traumatic brain injury. J Neurosci 1999;19: 6248-6256.

107 Micheau O, Tschopp J: Induction of TNF receptor I-mediated apoptosis via two sequential signaling complexes. Cell 2003; 114:181-190.

108 Lotocki G, de Rivero Vaccari JP, Perez ER, Alonso OF, Curbelo K, Keane RW, Dietrich WD: Therapeutic hypothermia modulates TNFR1 signaling in the traumatized brain via early transient activation of the JNK pathway and suppression of XIAP cleavage. Eur J Neurosci 2006;24:2283-2290.

109 Kelliher MA, Grimm S, Ishida Y, Kuo F, Stanger BZ, Leder P: The death domain kinase RIP mediates the TNF-induced NFkappaB signal. Immunity 1998;8:297-303.

-110 Yeh WC, Shahinian A, Speiser D, Kraunus J, Billia F, Wakeham A, de la Pompa JL, Ferrick $\mathrm{D}$, Hum $\mathrm{B}$, Iscove $\mathrm{N}$, Ohashi $\mathrm{P}$, Rothe M, Goeddel DV, Mak TW: Early lethality, functional NF-kappaB activation, and increased sensitivity to TNF-induced cell death in TRAF2-deficient mice. Immunity 1997;7:715-725.

111 Sluss HK, Barrett T, Derijard B, Davis RJ: Signal transduction by tumor necrosis factor mediated by JNK protein kinases. Mol Cell Biol 1994;14:8376-8384.
112 Ventura JJ, Hubner A, Zhang C, Flavell RA, Shokat KM, Davis RJ: Chemical genetic analysis of the time course of signal transduction by JNK. Mol Cell 2006;21:701710 .

113 Lamb JA, Ventura JJ, Hess P, Flavell RA, Davis RJ: JunD mediates survival signaling by the JNK signal transduction pathway. Mol Cell 2003;11:1479-1489.

114 Lee SJ, Zhou T, Choi C, Wang Z, Benveniste EN: Differential regulation and function of Fas expression on glial cells. J Immunol 2000;164:1277-1285.

-115 Shin SW, Park JW, Suh MH, Suh SI, Choe BK: Persistent expression of Fas/FasL mRNA in the mouse hippocampus after a single NMDA injection. J Neurochem 1998; 71:1773-1776

116 Beer R, Franz G, Schopf M, Reindl M, Zelger B, Schmutzhard E, Poewe W, Kampfl A: Expression of Fas and Fas ligand after experimental traumatic brain injury in the rat. J Cereb Blood Flow Metab 2000;20: 669-677.

117 Qiu J, Whalen MJ, Lowenstein P, Fiskum G, Fahy B, Darwish R, Aarabi B, Yuan J, Moskowitz MA: Upregulation of the Fas receptor death-inducing signaling complex after traumatic brain injury in mice and humans. J Neurosci 2002;22:3504-3511.

118 Casha S, Yu WR, Fehlings MG: FAS deficiency reduces apoptosis, spares axons and improves function after spinal cord injury. Exp Neurol 2005;196:390-400.

119 Demjen D, Klussmann S, Kleber S, Zuliani C, Stieltjes B, Metzger C, Hirt UA, Walczak H, Falk W, Essig M, Edler L, Krammer PH, Martin-Villalba A: Neutralization of CD95 ligand promotes regeneration and functional recovery after spinal cord injury. Nat Med 2004;10:389-395.

120 Martin-Villalba A, Hahne M, Kleber S, Vogel J, Falk W, Schenkel J, Krammer PH: Therapeutic neutralization of CD95-ligand and TNF attenuates brain damage in stroke. Cell Death Differ 2001;8:679-686.

121 Martin-Villalba A, Herr I, Jeremias I, Hahne M, Brandt R, Vogel J, Schenkel J, Herdegen T, Debatin KM: CD95 ligand (Fas-L/APO-1L) and tumor necrosis factorrelated apoptosis-inducing ligand mediate ischemia-induced apoptosis in neurons. J Neurosci 1999;19:3809-3817.

122 Lambert C, Landau AM, Desbarats J: Fasbeyond death: a regenerative role for Fas in the nervous system. Apoptosis 2003;8:551562.

123 Zuliani C, Kleber S, Klussmann S, Wenger T, Kenzelmann M, Schreglmann N, Martinez A, del Rio JA, Soriano E, Vodrazka P, Kuner R, Groene HJ, Herr I, Krammer PH, Martin-Villalba A: Control of neuronal branching by the death receptor CD95 (Fas/ Apo-1). Cell Death Differ 2006;13:31-40. 
-124 Desbarats J, Birge RB, Mimouni-Rongy M, Weinstein DE, Palerme JS, Newell MK: Fas engagement induces neurite growth through ERK activation and p35 upregulation. Nat Cell Biol 2003;5:118-125.

-125 Landau AM, Luk KC, Jones ML, SiegristJohnstone R, Young YK, Kouassi E, Rymar VV, Dagher A, Sadikot AF, Desbarats J: Defective Fas expression exacerbates neurotoxicity in a model of Parkinson's disease. J Exp Med 2005;202:575-581.

- 126 Staub F, Winkler A, Peters J, Kempski O, Baethmann A: Mechanisms of glial swelling by arachidonic acid. Acta Neurochir Suppl (Wien) 1994;60:20-23.

-127 Sevanian A, Kim E: Phospholipase A2 dependent release of fatty acids from peroxidized membranes. J Free Radic Biol Med 1985;1:263-271.

- 128 Dhillon HS, Donaldson D, Dempsey RJ Prasad MR: Regional levels of free fatty acids and Evans blue extravasation after experimental brain injury. J Neurotrauma 1994;11:405-415.

-129 Shohami E, Shapira Y, Yadid G, Reisfeld N, Yedgar S: Brain phospholipase A2 is activated after experimental closed head injury in the rat. J Neurochem 1989;53:15411546.

-130 Strauss KI, Barbe MF, Marshall RM, Raghupathi R, Mehta S, Narayan RK: Prolonged cyclooxygenase-2 induction in neurons and glia following traumatic brain injury in the rat. J Neurotrauma 2000;17:695-711.

-131 Shohami E, Shapira Y, Sidi A, Cotev S: Head injury induces increased prostaglandin synthesis in rat brain. J Cereb Blood Flow Metab 1987;7:58-63.

132 Kunz T, Marklund N, Hillered L, Oliw EH: Cyclooxygenase-2, prostaglandin synthases, and prostaglandin $\mathrm{H} 2$ metabolism in traumatic brain injury in the rat. J Neurotrauma 2002;19:1051-1064.

-133 Cernak I, O’Connor C, Vink R: Activation of cyclo-oxygenase-2 contributes to motor and cognitive dysfunction following diffuse traumatic brain injury in rats. Clin Exp Pharmacol Physiol 2001;28:922-925.

>134 Cernak I, O’Connor C, Vink R: Inhibition of cyclooxygenase 2 by nimesulide improves cognitive outcome more than motor outcome following diffuse traumatic brain injury in rats. Exp Brain Res 2002;147:193199.

-135 Zhao J, Moore AN, Clifton GL, Dash PK: Sulforaphane enhances aquaporin-4 expression and decreases cerebral edema following traumatic brain injury. J Neurosci Res 2005;82:499-506.

-136 Lee SC, Dickson DW, Brosnan CF: Interleukin-1, nitric oxide and reactive astrocytes. Brain Behav Immun 1995;9:345-354.

137 Allan SM, Rothwell NJ: Cytokines and acute neurodegeneration. Nat Rev Neurosci 2001;2:734-744.
138 Singhal A, Baker AJ, Hare GM, Reinders FX, Schlichter LC, Moulton RJ: Association between cerebrospinal fluid interleukin-6 concentrations and outcome after severe human traumatic brain injury. J Neurotrauma 2002;19:929-937.

139 Chiaretti A, Genovese O, Aloe L, Antonelli A, Piastra M, Polidori G, Di Rocco C: Interleukin 1beta and interleukin 6 relationship with paediatric head trauma severity and outcome. Childs Nerv Syst 2005;21:185193; discussion 194

140 Kinoshita K, Chatzipanteli K, Vitarbo E, Truettner JS, Alonso OF, Dietrich WD: Interleukin-1beta messenger ribonucleic acid and protein levels after fluid-percussion brain injury in rats: importance of injury severity and brain temperature. Neurosurgery 2002;51:195-203; discussion 203.

141 Boutin H, LeFeuvre RA, Horai R, Asano M, Iwakura Y, Rothwell NJ: Role of IL-1alpha and IL-1beta in ischemic brain damage. J Neurosci 2001;21:5528-5534.

142 Rothwell NJ, Luheshi GN: Interleukin 1 in the brain: biology, pathology and therapeutic target. Trends Neurosci 2000;23:618625.

143 Chung IY, Benveniste EN: Tumor necrosis factor-alpha production by astrocytes. Induction by lipopolysaccharide, IFN-gamma, and IL-1 beta. J Immunol 1990;144: 2999-3007.

144 Araujo DM, Cotman CW: Basic FGF in astroglial, microglial, and neuronal cultures: characterization of binding sites and modulation of release by lymphokines and trophic factors. J Neurosci 1992;12:16681678.

145 da Cunha A, Vitkovic L: Transforming growth factor-beta 1 (TGF-beta 1) expression and regulation in rat cortical astrocytes. J Neuroimmunol 1992;36:157-169.

146 Herx LM, Rivest S, Yong VW: Central nervous system-initiated inflammation and neurotrophism in trauma: IL-1 beta is required for the production of ciliary neurotrophic factor. J Immunol 2000; 165:22322239.

147 Friedman WJ, Thakur S, Seidman L, Rabson $\mathrm{AB}$ : Regulation of nerve growth factor mRNA by interleukin-1 in rat hippocampal astrocytes is mediated by NFkappaB. J Biol Chem 1996;271:31115-31120.

148 Mason JL, Suzuki K, Chaplin DD, Matsushima GK: Interleukin-1beta promotes repair of the CNS. J Neurosci 2001;21:70467052.

149 Saul TG, Ducker TB: Effect of intracranial pressure monitoring and aggressive treatment on mortality in severe head injury. J Neurosurg 1982;56:498-503.

150 Sarabia R, Lobato RD, Rivas JJ, Cordobes F, Rubio J, Cabrera A, Gomez P, Munoz MJ, Madera A: Cerebral hemisphere swelling in severe head injury patients. Acta Neurochir (Wien) 1988;42(suppl):40-46.
151 Miller JD, Becker DP, Ward JD, Sullivan HG, Adams WE, Rosner MJ: Significance of intracranial hypertension in severe head injury. J Neurosurg 1977;47:503-516.

152 Levin HS, Eisenberg HM, Gary HE, Marmarou A, Foulkes MA, Jane JA, Marshall LF, Portman SM: Intracranial hypertension in relation to memory functioning during the first year after severe head injury. Neurosurgery 1991;28:196-199; discussion 200.

153 Eisenberg HM, Gary HE Jr, Aldrich EF, Saydjari C, Turner B, Foulkes MA, Jane JA, Marmarou A, Marshall LF, Young HF: Initial CT findings in 753 patients with severe head injury. A report from the NIH Traumatic Coma Data Bank. J Neurosurg 1990; 73:688-698.

154 Klatzo I: Presidental address: neuropathological aspects of brain edema. J Neuropathol Exp Neurol 1967;26:1-14.

155 Barzo P, Marmarou A, Fatouros P, Corwin F, Dunbar J: Magnetic resonance imagingmonitored acute blood-brain barrier changes in experimental traumatic brain injury. J Neurosurg 1996;85:1113-1121.

156 Barzo P, Marmarou A, Fatouros P, Hayasaki K, Corwin F: Biphasic pathophysiological response of vasogenic and cellular edema in traumatic brain swelling. Acta Neurochir 1997;70(suppl):119-122.

157 Barzo P, Marmarou A, Fatouros P, Hayasaki K, Corwin F: Contribution of vasogenic and cellular edema to traumatic brain swelling measured by diffusion-weighted imaging. J Neurosurg 1997;87:900-907.

158 Ito J, Marmarou A, Barzo P, Fatouros P, Corwin F: Characterization of edema by diffusion-weighted imaging in experimental traumatic brain injury. J Neurosurg 1996;84:97-103.

159 Unterberg AW, Stover J, Kress B, Kiening KL: Edema and brain trauma. Neuroscience 2004;129:1021-1029.

160 Gotoh O, Asano T, Koide T, Takakura K: Ischemic brain edema following occlusion of the middle cerebral artery in the rat. I: The time courses of the brain water, sodium and potassium contents and blood-brain barrier permeability to ${ }^{125} \mathrm{I}$-albumin. Stroke 1985;16:101-109.

161 Aldrich EF, Eisenberg HM, Saydjari C, Luerssen TG, Foulkes MA, Jane JA, Marshall LF, Marmarou A, Young HF: Diffuse brain swelling in severely head-injured children: a report from the NIH Traumatic Coma Data Bank. J Neurosurg 1992;76: 450-454.

162 Betz AL: Transport of ions across the bloodbrain barrier. Fed Proc 1986;45:20502054.

163 Kimelberg HK: Astrocytic edema in CNS trauma. J Neurotrauma 1992;9(suppl 1): S71-S81. 
164 Bullock R, Maxwell WL, Graham DI, Teasdale GM, Adams JH: Glial swelling following human cerebral contusion: an ultrastructural study. J Neurol Neurosurg Psychiatry 1991;54:427-434.

- 165 Katayama Y, Tsubokawa T, Miyazaki S, Kawamata T, Yoshino A: Oedema fluid formation within contused brain tissue as a cause of medically uncontrollable elevation of intracranial pressure: the role of surgical therapy. Acta Neurochir Suppl (Wien) 1990;51:308-310.

166 Nilsson P, Hillered L, Olsson Y, Sheardown MJ, Hansen AJ: Regional changes in interstitial $\mathrm{K}^{+}$and $\mathrm{Ca}^{2+}$ levels following cortical compression contusion trauma in rats. $\mathrm{J}$ Cereb Blood Flow Metab 1993;13:183-192.

167 Kimelberg HK, Rutledge E, Goderie S, Charniga C: Astrocytic swelling due to hypotonic or high $\mathrm{K}^{+}$medium causes inhibition of glutamate and aspartate uptake and increases their release. J Cereb Blood Flow Metab 1995;15:409-416.

168 Barron KD, Dentinger MP, Kimelberg HK, Nelson LR, Bourke RS, Keegan S, Mankes R, Cragoe EJ Jr: Ultrastructural features of a brain injury model in cat. I. Vascular and neuroglial changes and the prevention of astroglial swelling by a fluorenyl (aryloxy) alkanoic acid derivative (L-644,711). Acta Neuropathol (Berl) 1988;75:295-307.

169 Kimelberg HK, Barron KD, Bourke RS, Nelson LR, Cragoe EJ: Brain anti-cytoxic edema agents. Prog Clin Biol Res 1990;361: 363-385.

170 Nielsen S, Nagelhus EA, Amiry-Moghaddam M, Bourque C, Agre P, Ottersen OP: Specialized membrane domains for water transport in glial cells: high-resolution immunogold cytochemistry of aquaporin-4 in rat brain. J Neurosci 1997;17:171-180.

- 171 Nicchia GP, Nico B, Camassa LM, Mola MG, Loh N, Dermietzel R, Spray DC, Svelto $M$, Frigeri A: The role of aquaporin- 4 in the blood-brain barrier development and integrity: studies in animal and cell culture models. Neuroscience 2004;129:935-945.
172 Guo Q, Sayeed I, Baronne LM, Hoffman SW, Guennoun R, Stein DG: Progesterone administration modulates AQP4 expression and edema after traumatic brain injury in male rats. Exp Neurol 2006;198:469478.

173 Papadopoulos MC, Verkman AS: Aquaporin- 4 and brain edema. Pediatr Nephrol 2007;22:778-784.

174 Verkman AS, Yang B, Song Y, Manley GT, $\mathrm{Ma}$ T: Role of water channels in fluid transport studied by phenotype analysis of aquaporin knockout mice. Exp Physiol 2000;85: 233S-241S.

175 Badaut J, Lasbennes F, Magistretti PJ, Regli L: Aquaporins in brain: distribution, physiology, and pathophysiology. J Cereb Blood Flow Metab 2002;22:367-378.

176 Amiry-Moghaddam M, Xue R, Haug FM, Neely JD, Bhardwaj A, Agre P, Adams ME, Froehner SC, Mori S, Ottersen OP: Alphasyntrophin deletion removes the perivascular but not endothelial pool of aquaporin- 4 at the blood-brain barrier and delays the development of brain edema in an experimental model of acute hyponatremia. Faseb J 2004;18:542-544.

177 Manley GT, Fujimura M, Ma T, Noshita N, Filiz F, Bollen AW, Chan P, Verkman AS: Aquaporin-4 deletion in mice reduces brain edema after acute water intoxication and ischemic stroke. Nat Med 2000;6:159-163.

178 Kiening KL, van Landeghem FK, Schreiber S, Thomale UW, von Deimling A, Unterberg AW, Stover JF: Decreased hemispheric aquaporin-4 is linked to evolving brain edema following controlled cortical impact injury in rats. Neurosci Lett 2002;324:105108

179 Sun MC, Honey CR, Berk C, Wong NL, Tsui JK: Regulation of aquaporin-4 in a traumatic brain injury model in rats. J Neurosurg 2003;98:565-569.
180 Vizuete ML, Venero JL, Vargas C, Ilundain AA, Echevarria M, Machado A, Cano J: Differential upregulation of aquaporin-4 mRNA expression in reactive astrocytes after brain injury: potential role in brain edema. Neurobiol Dis 1999;6:245-258.

181 Saadoun S, Papadopoulos MC, Watanabe H, Yan D, Manley GT, Verkman AS: Involvement of aquaporin-4 in astroglial cell migration and glial scar formation. J Cell Sci 2005;118:5691-5698.

182 Auguste KI, Jin S, Uchida K, Yan D, Manley GT, Papadopoulos MC, Verkman AS: Greatly impaired migration of implanted aquaporin-4-deficient astroglial cells in mouse brain toward a site of injury. FASEB J 2007;21:108-116.

183 Ridet JL, Malhotra SK, Privat A, Gage FH: Reactive astrocytes: cellular and molecular cues to biological function. Trends Neurosci 1997;20:570-577.

184 Eddleston M, Mucke L: Molecular profile of reactive astrocytes - implications for their role in neurologic disease. Neuroscience 1993;54:15-36.

185 Norenberg MD: Astrocyte responses to CNS injury. J Neuropathol Exp Neurol 1994;53:213-220.

186 Davies SJ, Field PM, Raisman G: Regeneration of cut adult axons fails even in the presence of continuous aligned glial pathways. Exp Neurol 1996;142:203-216.

187 Wilhelmsson U, Li L, Pekna M, Berthold $\mathrm{CH}$, Blom S, Eliasson C, Renner O, Bushong E, Ellisman M, Morgan TE, Pekny M: Absence of glial fibrillary acidic protein and vimentin prevents hypertrophy of astrocytic processes and improves post-traumatic regeneration. J Neurosci 2004;24: 5016-5021.

188 Moon LD, Brecknell JE, Franklin RJ, Dunnett SB, Fawcett JW: Robust regeneration of CNS axons through a track depleted of CNS glia. Exp Neurol 2000;161:49-66. 